\title{
Ports and Ladders: The Nature and Relevance of Internal Labor Markets in a Changing World
}

\author{
PAUL OSTERMAN \\ M. DIANE BURTON \\ MIT Sloan School of Management
}

\section{Overview}

Many believe that the nature of careers has changed dramatically in the past twenty years. One scholar writes that internal labor markets have been 'demolished', while a human resources manager at Intel comments that, in contrast to the past, today, 'You own your own employability. You are responsible' (Knoke 2001: 31). The idea of the 'boundaryless career' seems increasingly popular (Arthur and Rousseau 1996).

If it is in fact true that the old rules for organizing work have disappeared, this would represent a fundamental change for employees. It would also have major implications for how scholars think about the labor market. Not surprisingly, the reality is more complicated, with evidence of both change and stability in the nature of the employment relationship. In this chapter we discuss the nature of these developments and their implications for the internal labor market literature.

\subsection{What are Internal Labor Markets and Why Are They Important?}

In their classic book, Internal Labor Markets and Manpower Analysis, Peter Doeringer and Michael Piore (1971) define an internal labor market (ILM) as 'an administrative unit, such as a manufacturing plant, within which the pricing and allocation of labor is governed by a set of administrative rules or procedures' (Doeringer and Piore 1971: 2). Doeringer and Piore described a world in which people were hired at the bottom of a job ladder, in so-called 'ports of entry', and then moved up that ladder over their careers. Wages were open to market forces at these entry points but in setting compensation the firm placed considerable emphasis upon internal equity and customary differentials. Pay determination involved careful analysis of relative wages internally and more casual attention to the external market. Rules regarding work allocation and duty distribution were similarly influenced by tradition. Skills were firm-specific and informal training played an important role in firm operations.

The key insight in the ILM perspective is that organizations are the locus of employment outcomes. The most important decisions regarding wages and employment are made by organizations. While at one level obvious, this perspective contrasted sharply with standard economic theory, which gave almost exclusive attention to the external market. The ILM lens shifted attention to the behavior of organizations and in doing so, alerted scholars from a variety of academic disciplines to the phenomena of careers within organizations.

The recognition that economic outcomes are determined by a complicated mixture of social, political, and economic factors returns to a point made nearly fifty years ago by Alvin Gouldner (1954) in his famous study of how work rules emerge in industrial settings. Gouldner showed in great detail how management and employees interacted in setting the rules that governed the workplace and how the actual system was a political bargain that reflected social as well as economic considerations. 
In contrast to the standard economic view, which interprets work rules as the result of optimizing behavior, and in contrast to the Weberian view of bureaucracy, which also emphasizes efficiency and rationality, the ILM perspective forces attention to custom, power, and norms. The intellectual roots of the ILM tradition come from the industrial relations academics - a group of policy-oriented pragmatists who moved easily between academia and practice-who were active during the Depression, World War II, and the postwar period. ${ }^{1}$ The ILM perspective, as an interdisciplinary synthesis informed by deep knowledge of work and organizations, offered a realistic view of organizational life and labor market outcomes in a world where most people spent their careers within large bureaucracies.

A key question is whether the insights of the ILM perspective have the same relevance in a world where long-term employment in bureaucratic organizations is less common, academic disciplinary boundaries have become more rigid, and the subjects of scholarly inquiry are increasingly distant from the world of practice. We address this question by explicating what we believe to be the core ideas and values associated with the ILM perspective, assessing the empirical and theoretical progress to date, and proposing a future research agenda.

\subsection{Core Ideas and Values Associated with the ILM Perspective}

The original Doeringer and Piore analysis asserts the importance of both market and nonmarket forces in shaping ILMs. There is no single clear statement of what these nonmarket forces are, but a reading of the literature suggests that custom, norms, and power are the main considerations (Jacoby 1985). Customs arise because ILMs create stable work groups (or stable work groups create ILMs) and, as a considerable literature documents, this leads to expectations regarding work effort, pay, and the like. There is a long-standing literature on these themes (Crozier 1964; Gouldner 1954; Roy 1952). These expectations can be enforced, even in nonunion settings, by withholding of effort. As a result, firms frequently pay more attention to custom (e.g. in setting wages) than they do to supply and demand in the market.

Norms operate like customs but refer more to the attitudes of management. Throughout most of the postwar period the norms of managers were grounded in the academic literature termed the Human Relations School. ${ }^{2}$ As Mauro Guillen points out, the central idea in this line of thought, beginning with Elton Mayo and elaborated by numerous management theorists, was that 'neglecting the morale, sentiments, and emotions of both the worker and manager would set limits to the firm's productivity and profitability' (Guillen 1994: 58). ${ }^{3}$ In contrast to the earlier engineering-oriented scientific management approach to boosting performance (Scott 1992: 34-5), the human relations perspective led to the diffusion of human resource practices such as morale surveys and employee suggestion systems. More to the point, it reinforced the norm that the firm should (ideally) make a long-term commitment to its labor force.

Direct exercise of union power and government intervention also shaped ILMs. One of the major goals of unions was to establish predictable rules and procedures that eliminated the arbitrary behavior of foremen under the 'drive system', which typified employment relationships during the first third of the

\footnotetext{
${ }^{1}$ These include for example, John Dunlop, Clark Kerr, Charles Meyers, and George Schultz.

${ }^{2}$ For a summary of the Human Relations School, see Scott (1992: 57-61) Barley and Kunda (1992), and Bendix (1956).

${ }^{3}$ See and Mayo (1945) Roethlisberger and Dickson (1939) for descriptions of the original research that formed the foundation of the Human Relations School. See McGregor (1960), for the most well-known summary of the underlying principles and philosophy of the Human Relations School.
} 
twentieth century. As they gained strength, unions bargained for seniority rights and for job demarcations, which in turn led to job ladders. Sometimes nonunion firms imitated union practice to avoid unionization. In other instances nonunion companies, such as Eastman Kodak, developed their own form of 'welfare capitalism', mixing bureaucratic practices with attention to human relations (Jacoby 1997). The government shaped ILMs by setting rules regarding pay and benefits and by legitimizing union practices such as seniority. A particularly important period was during World War II when the War Labor Board essentially dictated employment practices to firms and to unions.

Economic considerations were also important. For example, Doeringer and Piore gave considerable weight to the role of ILMs in creating a system for efficiently training workers and retaining them. Job ladders accomplish both tasks. Workers higher in the ladder are protected from competition from those below and hence will be willing to provide training. By the same token, the gains to be had from seniority reduce the incentive of trained employees to leave, since they would have to start at the bottom in their next firm.

At the end of the day, the ILM idea is about how social, political, and economic forces act together to determine what happens to people at work. It is this mixture that gives the idea so much interest and power.

\subsection{Literature Review and Outstanding Questions}

The original Doeringer-Piore formulation focused on blue-collar work in large and medium-sized firms. How well these ideas generalized to the rest of the labor market was unclear. To some extent, Doeringer and Piore generalized via their construct of the secondary labor market to the sector of the economy with no job ladders or other incentives for long-term attachment. However, this idea was mainly aimed at understanding low-wage labor markets and the problem of poverty. What about the rest of the economy, both the white-collar world and also the many nonindustrial firms outside of the poverty job market?

At a theoretical level, scholars have suggested that ILMs referred not to specific practices (e.g. rigid ports of entry), but to the idea that the rules governing work are set administratively and are determined by a range of considerations, economic and noneconomic. Hence, it is not problematic that occupational clusters operate under different ILM rules and constitute different ILM subsystems (Osterman 1987).

Empirical investigations of ILMs in non-blue-collar settings have been relatively rare; however, there are a few notable studies. Rosabeth Moss Kanter's (1977) description of Indsco in Men and Women of the Corporation portrays a world of hierarchies and ladders in which upward mobility is the sine qua non of success. A seminal study of the California Civil Service (Baron and Bielby 1986) yielded three key insights: first, there are important differences in employment arrangements among firms within an industry or sector; second, the gender composition of jobs influences both the quality and the extent to which they are connected to job ladders that provide upward mobility; and third, job titles-positions on the ladder-and their associated rewards are subject to social and political forces. Other notable studies of managerial careers are those of DiPrete (1989), Jackall (1988), and Rosenbaum (1984). Although they do not all use the ILM vocabulary, their findings are broadly consistent with the ILM perspective.

In the economics literature, Baker, Gibbs, and Holmstrom $(\underline{1994 a}, b)$ analyzed career patterns and wages in a bank, using longitudinal personnel data from the 1980s. They found that some of the Doeringer-Piore formulation did not apply in this setting (for example, there were not well defined ports 
of entry). However, they identified clear job ladders and found wages sheltered from the external market. ${ }^{4}$

All of these studies are rich, detailed examinations of organizational settings over time and are attentive to the social and economic aspects of career dynamics. While the research on ILMs may be overbalanced towards blue-collar work, the existing studies verify that the concept is appropriate for white-collar work.

However, the literature has a bias towards large firms and is virtually silent about how work is organized in smaller firms. This is an important issue, given that most employers in America are small, with under 100 employees, and these firms account of over half of all employment. ${ }^{5}{ }^{[5]}$ It is troublesome today because, as we discuss below, many new ideas in employment are emanating from entrepreneurial small firms.

Recent research has elaborated some themes from the original ILM literature. The role of power in shaping work organization is a key element of the ILM perspective and recent work emphasizes alternative conceptions of power. For example, there is evidence that whether or not jobs are part of longer ladders and how work is compensated is influenced by the gender composition of the labor supply (Baron and Newman 1990). Thus, gender considerations affect work organization as opposed to work organization and pay determining who applies for jobs. Similarly, Abbott's work on the dynamics of competition among professions illustrates how professional groups deploy their power within organizations and the licensing power of the state to shape job duties and career paths (Abbott 1988). Additionally, a recent spate of regulations regarding equal employment opportunity has had a substantial impact on how employment is organized within firms. A final social consideration in the construction of ILMs is the power of imitation, or what sociologists refer to as isomorphism (DiMaggio and Powell 1983; Meyer and Rowan 1977). The central idea is that organizations achieve legitimacy by copying the practices of prominent others. While the initial adopters may have had sound reasons for implementing practices, later adopters may be imitating pioneers in order to maintain appearances (Tolbert and Zucker 1983).

These examples illustrate one of the potential extensions of the ILM perspective: considering forms of collective power outside of organizations, including specific work and occupational groups and unions. These forces reassert the importance of the social and the political in the labor market.

The emergence of agency theory and organizational economics has led economic theorists to explanations of ILMs focused on efficiency considerations. In this context, long-term employment relationships are seen as solving incentive and ownership problems. They are interpreted as mechanisms for inducing workers to undertake actions in line with the desires of management, as well as a useful device for solving the challenges of monitoring and enforcement (Gibbons and Waldman 2000). While the economic explanations of ILM practices are useful and important, they treat the organization as simply the transmission belt for a set of considerations that are removed from the dynamics of social and political life. In our view, what gives the ILM idea power, and the reason that it is important, lies precisely in these social and political factors. Social and political factors also introduce

\footnotetext{
${ }^{4}$ They found that there were substantial cohort effects in wage setting, which implies that market considerations were attenuated.

${ }^{5}$ In 1997, 97.6 percent of establishments were under 100 employees and these accounted for 54.6 percent of all jobs (Knoke 2001: 84).
} 
inertia and explain why organizations do not immediately adapt when economic incentives change. Therefore, the determination and distribution of economic outcomes, wages, and careers must be understood from a broader perspective.

\subsection{The Changing Rules of Employment}

A central challenge confronting the ILM literature is understanding the implications of two decades of organizational restructuring. Thus far, the literature has been unsuccessful in explaining how ILM structures evolve over time. This was unproblematic in the context of the long postwar expansion where the basic structure of the American economy seemed stable. However, beginning in the mid-1980s, stability was called into question, and firms started to rewrite the rules of employment. After nearly two decades of turmoil, it is reasonable to ask whether the ILM idea is still useful, either as a description of reality or as a theoretical way of understanding the employment relationship.

The earlier discussion points to three questions that go to the heart of whether the ILM idea still makes sense. First and most basically, do people still have stable careers within organizations? Second, how have the rules governing employment changed? Finally, do social forces-customs, norms, power, and imitation-still play any role in a world in which market forces seem increasingly dominant? As we will see, the empirical evidence is unclear about the answers to these questions. The next section reviews what we know about how the rules of employment have changed.

\subsubsection{Employment Stability}

ILMs cannot exist without employment stability; thus the natural first question is what has become of job security. There is reason to believe job security has been undermined for most employees. A much larger fraction of layoffs are now permanent instead of temporary, and firms are more willing to layoff employees for reasons other than declining sales. Osterman, using announced layoffs in the Wall Street Journal, classified the reasons for layoffs in 1974 and 1994 by whether they were due to poor sales or to restructuring. The fraction due to restructuring rose to 50 percent from 30 percent (Osterman 1999: 39). In a similar exercise, Farber and Hallock studied changes in the stock market reaction to layoffs over time and found that layoffs in the 1990s were seen in a positive light whereas stock prices previously had been punished (Farber and Hallock 1999).

There are other indications that job security has weakened. Farber (2001) analyzed biannual data on employee dislocation (permanent layoffs due to business decisions of firms) and found that while there is a strong cyclical component to dislocation, during the mid-1990s there was more dislocation than would be expected given the tight labor market of that period.

Given these findings one would expect that summary data on job security would show a sharp decline. But this is where the picture gets murky. The best available data are the job tenure information collected every two years in a supplement to the Current Population Survey about the number of years the respondent has worked for the same employer. Table 18.1 provides these data for the entire labor force and for men and women, both with and without age distinctions. The basic story is clear. There is a downward trend in the proportion of men holding long-tenure jobs. The trend is especially pronounced for middle-age men, whom one would expect to be well ensconced in their organizations. However, the trend is quite different for women who, by contrast, have experienced a long-term increase in the 
fraction holding high tenure jobs. The net effect is a mild decline (but a decline nonetheless) for the labor force as a whole in long-tenure employment.

Table 18.1: Percent of employees with ten or more years of tenure with current employer

\begin{tabular}{|l|c|c|c|c|}
\hline & $\mathbf{1 9 8 3}$ & $\mathbf{1 9 9 1}$ & $\mathbf{1 9 9 6}$ & $\mathbf{2 0 0 0}$ \\
\hline Both sexes 25 and up & 31.9 & 32.2 & 30.5 & 31.7 \\
\hline Both sexes age 40-44 & 38.1 & 39.3 & 36.1 & 35.9 \\
\hline Both sexes age 50-54 & 53.5 & 51.4 & 50.4 & 48.6 \\
\hline Men 25 and up & 37.7 & 35.9 & 33.1 & 33.6 \\
\hline Men age 40-44 & 51.1 & 46.3 & 41.7 & 40.4 \\
\hline Men age 50-54 & 62.3 & 58.5 & 54.9 & 51.6 \\
\hline Women 25 and up & 24.9 & 28.2 & 27.6 & 29.5 \\
\hline Women age 40-44 & 23.4 & 32.0 & 30.4 & 31.4 \\
\hline Women age 50-54 & 42.5 & 43.4 & 45.8 & 45.6 \\
\hline
\end{tabular}

Source: Bureau of Labor Statistics, current population survey.

It is easy to see, from looking at the data for men, why observers may feel that ILMs are crumbling. Although even in 2000 over half of men age 50-54 held long-tenure jobs, the decline has been sharp. Furthermore, the trend, if extrapolated forward, is not promising. However, the longer job tenure of women offsets much of what has happened to men. There is clearly a story to be told about why the fortunes of men and women diverge. But for the purposes of understanding employment systems, the first approximation is that ILMs seem to be in mild retreat, but nothing as dramatic as the earlier expressions of alarm would suggest.

Additional evidence in the direction of moderation is found in the Bureau of Labor Statistic's survey of contingent work. As part of yet another supplement to the Current Population Survey, respondents are asked every two years about whether they hold contingent jobs. There are three alternative definitions of what is meant by contingent work. The most expansive includes employees who do not expect their jobs to last indefinitely (for reasons other than personal). Among people between the ages of 25 and 64 in the survey of February 2001, 3.2 percent reported that they held contingent jobs. This compares with 3.9 percent in 1995, 3.5 percent in 1997, and 3.3 percent in 1999. There is thus no upward trend in the fraction of the workforce holding precarious jobs.

The mixed story told by these data on tenure and contingent work explains why there is a debate about what is happening to career jobs. A recent exchange between Peter Cappelli (1999) and Sanford Jacoby $(1999 a, b)$ does an excellent job of clarifying the disagreement. Cappelli argues that career jobs have been destroyed. He focuses mainly on managers (who are most likely to be men). He discredits the tenure data by pointing out that they reflect quits as well as layoffs - two forces that move in opposite directions and would in aggregate reveal more stability than exists in reality. Finally, he argues that if we focus only on large employers, who are the real drivers of the economy, we would also see much more insecurity than is reflected in the aggregate data. In reply, Jacoby argues that male managers in large firms represent only a small fraction of the economy and that changes elsewhere have been far less dramatic. According to Jacoby, firms have shifted some employment risk to employees; however, this has by no means changed the fundamental character of the employment relationship. 
What, then, can we conclude from this conflicting evidence? On their face, the data suggest that ILMs have declined, but that for most people the circumstances of their working life have not changed. We think that this is a fair conclusion, but it overlooks how the changes might affect the attitudes and expectations of employees. A brief parable illustrates this point. Imagine that one hundred people worked together steadily for a number of years with no untoward events. One day someone walks in and summarily fires one person and then walks out. It is true, as the statistician would argue, that only 1 percent of the group has lost their job. However, the world has been turned upside down for everyone. The remaining ninety-nine employees will come to work everyday wondering when their turn will come. This worry will inevitably alter a wide range of behaviors. The actual changes described in this chapter are more extensive than one in one hundred and it is reasonable to believe that their consequences have reverberated broadly.

\subsubsection{Temporary and Contract Work}

A core characteristic of ILMs is that people who work for the organization are part of the administrative unit that sets employment conditions. Employees are members of the firm. This assumption seemingly has been undermined by the rapid emergence of new ways of organizing work and, in particular, by the growing use of staffing firms and outsourcing contracts. Staffing firms (aka temporary help agencies) supply employees who work on-site in a client firm, whereas outsourcing firms take over activities that were previously done in-house. Both appear to threaten the integrity of ILMs.

According to David Autor (2001), between 1979 and 1995 the temporary help supply industry in the United States increased its daily head count from 435,000 to 2.4 million workers. ${ }^{6}$ Although, as Susan Houseman has shown (Houseman 2001), many firms still use temporary help agencies in their oldfashioned role of meeting peak loads and filling temporary vacancies, what is striking about these firms is the new roles they are playing. They have penetrated into a wide range of occupations, and they play an important role in many firms' recruiting and training strategies.

In a similar vein, firms are increasingly contracting out services. This happens at the low end of the labor market where, for example, nearly all building service workers in large buildings now work for contracting firms rather than building owners. However, this also is happening at the high end, as the growth of computer outsourcing by firms such as EDS and IBM testifies.

The most striking pattern in the use of temporary workers is their role in relieving firms of the implicit constraints imposed by ILMs. For example, case studies by Houseman, Kalleberg, and Erickcek (forthcoming) illustrate a widely commented upon pattern: the use of staffing agencies as forms of probationary employment, thereby releasing firms from the constraints of formal probationary periods. Employers use temporary help firms as a recruiting device (as a labor market intermediary) and the movement from 'temp to perm' is not uncommon. ${ }^{7}$ In a similar vein, Autor (2001) shows that in those states in which legislation restricted employment-at-will practices temporary help firms grew at a faster pace than average.

\footnotetext{
${ }^{6}$ According to Autor, '[T]he Temporary Help Supply (THS) industry in the U.S. grew at eleven percent annuallyover five times more rapidly than U.S. non-farm employment' (see Autor 2001: 1).

${ }^{7}$ In Osterman's National Survey of Establishments 24 percent of temporaries were eventually hired by firm to which they were assigned. Census data reports that 57 percent of workers in a temporary job were in a permanent job the next year (Cappelli 1999: 142).
} 
The use of staffing firms to loosen the constraints of ILMs goes beyond these examples. Based on their survey of establishments, Abraham and Taylor (1996) concluded that one motivation of contracting out was to induce greater flexibility in the wage structure. Although this is often taken to mean paying lower wages (and avoiding benefits), the use of staffing firms can also sometimes enable firms to pay certain categories of workers higher wages without being forced by the wage structure of the ILM to increase the compensation of all employees. Abraham and Taylor find evidence of this high-wage pattern in their data on contracting out, and Houseman, Kalleberg, and Erickcek (forthcoming) also found examples of exactly this usage in their case studies of temporary workers in health care.

Beyond these specific motivations, the message implicit in the growing use of temporary and contract workers is that the firm no longer considers workers to be part of the organization. Clearly this message is very subversive of ILMs. Table 18.2 shows the fraction of the labor force employed in staffing firms and contracting firms. It turns out that, although the growth rates are quite high when the baseline is the 1970 s or early 1980s, the actual numbers are modest and there was relatively little growth in the 1990s. The largest group of employees are independent contractors, but this group differs markedly from the others as evidenced by the fact that the majority of them prefer their employment situation to traditional employment, whereas the majority of temporary and on-call workers would rather have standard jobs (Golden and Appelbaum 1992).

Table 18.2: Alternative employment over time (\% of labor force)

\begin{tabular}{|l|l|l|l|l|}
\hline & $\mathbf{1 9 9 5}$ & $\mathbf{1 9 9 7}$ & $\mathbf{1 9 9 9}$ & $\mathbf{2 0 0 1}$ \\
\hline Independent contractor or freelance & 6.7 & 6.7 & 6.3 & 6.4 \\
\hline On call & 1.7 & 1.6 & 1.5 & 1.6 \\
\hline Agency temporaries & 1.0 & 1.0 & 0.9 & 0.9 \\
\hline Contract workers & 0.5 & 0.6 & 0.6 & 0.5 \\
\hline
\end{tabular}

Source: Bureau of Labor Statistics, current population survey.

These low numbers are a bit misleading because the high turnover of temporary workers implies that more people flow through these jobs in a given year than appear in them at any point in time. Autor (2001) estimates, for example, that between seven and eight times as many people hold temporary jobs over the course of a year than at any point in time. Nonetheless, from the ILM perspective, these workers do not account for very much of employment.

\subsubsection{Wage Setting}

Wage setting is obviously a core aspect of the employment relationship ${ }^{8}$. The traditional ILM story was that firms paid more attention to establishing a stable and fair internal wage structure than to rewarding either individual performance or responding to market forces. They did so because customary wage differentials were believed to be essential to the continued social functioning of the firm. The mechanics of wage setting involved extensive attention to internal pay setting (frequently via techniques such as Hay points) and little attention to salary surveys and other market wage data. It is also worth noting that

\footnotetext{
${ }^{8}$ Ruthanne Huising did most of the research underlying this section.
} 
Hay points are allocated to roles rather than individuals and thus give no credit to individual performance.

Increasing wage inequality in the past twenty-five years suggests a potential ILM breakdown. It does not prove the point since inequality could increase via differential growth rates of firms and occupations even in the face of stable internal wage structures. However, growing wage differentials, combined with new managerial rhetoric about pay for performance, implies that something about the wage-setting process has changed.

There are two senses in which ILMs might break down: firms might pay more attention to market wages with ILMs no longer mitigating market forces, or rewards for individual performance might increase and the social strictures on wage differences erode. Either would imply that ILMs have attenuated with respect to pay. However, the evidence suggests the trends are in favor of the former-a breakdown of ILM shelters against market wages.

Observations of wage setting suggest that firms are making increased use of pay surveys ${ }^{9}$ and this trend is augmented by the wide availability of salary data via web sites such as salary.com and salaryexpert.com. Furthermore, Levine et al. (2002) show that traditional pay differentials between large and small firms are eroding. They conclude that this cannot be entirely explained by changes in workforce characteristics and that the convergence shows a 'decline in the institutionalist pressures that formerly led to a size-wage effect' (Levine et al. 2002: 73).

The evidence, it should be noted, is not uniformly in the same direction. Levine et al. also find no increase in the sensitivity of employers' wage levels to local labor market conditions. However, other shifts in firms' wage-setting practices add support for the idea that wages are less insulated than in the past. For example, there is growing use of 'broadbanding' - a reduction in the number of pay gradeswhich enables firms to link individuals' pay more closely both to their performance and to the market wage that they might get (Berger and Berger 2000). Front-line managers who set pay for specific jobs are able to utilize market pay data. Levine et al. (2002: 52) conclude that 'broadbanding results in pay to individuals that is more representative of external market wages for that individual'.

Furthermore, pay-for-performance schemes have been widely adopted both across firms and across categories of employees, and these schemes tend to undermine traditional pay structures. According to one survey, 27.1 percent of non-exempt employees received some of their pay via bonus or incentive plans in 1994 and the fraction had increased to 44.8 percent by 1998 (HR Focus July 2000). ${ }^{10} \mathrm{~A}$ survey by the Federal Reserve Bank found that in 1998, 69 percent of lower level employees (i.e. not managers or professionals) received at least one form of variable pay (Lebow et al. 1999). Finally, an analysis of Hay data in 1986 and 1992 found that the percentage of employees who received bonuses increased from 19.6 percent to 32 percent (O'Shaughnessy, Levine, and Cappelli 2000).

Taken as a whole, it seems that wage setting is more open to market forces than in the past and that the importance of traditional internal structures has diminished as pay targeted to individuals has increased. This is not to say, however, that pay is now set simply via supply and demand or by individual performance. There is still evidence that internal structures remain important. For example, in their analysis of pay in a large bank in the late 1980s, Baker, Gibbs, and Holmstrom (1994b) found clear

\footnotetext{
${ }^{9}$ Large companies obtain, on average, eleven surveys per year (see Sibson 1990).

${ }^{10}$ This is based on a survey of Fortune 1000 firms by Buck Consulting.
} 
evidence that the pay level of hiring cohorts relative to each other remained stable over time, a finding that implies that the internal structure shelters pay from the market. Similarly, Levine et al. (2002) utilize a community salary survey conducted by the Federal Reserve Bank between 1956 and 1996 in Cleveland to analyze the persistence of internal structure differentials and find them to be relatively constant across the 1980s and 1990s, indicating no increased sensitivity of employer pay practices to market pressures.

The best conclusion, then, is that the role of ILMs in pay setting is weaker than in the past but that they remain an important part of pay determination.

\subsubsection{Changing Work Rules}

A central element of ILMs, at least in blue-collar settings, was rigid job descriptions. This was particularly true in the union sector but extended into nonunion firms as well. Because firms could lay people off without constraint, unions sought well-defined jobs as a form of protection from employers who would combine assignments in order to increase layoffs. In addition, when promotions and salary increases came from climbing a job ladder, the 'rungs' needed to be well defined.

The system of seniority and tightly defined jobs was rational and effective as long as firms' environment was stable. However, as the product market forced firms to innovate rapidly and focus on quality, the rigidities inherent in the old ILM system became a liability. This became painfully evident as competitors, notably the Japanese, gained better productivity and higher quality from more flexible production methods. The response in the United States was high-performance work systems.

In the past decade and a half many firms, in both manufacturing and services, implemented team-based production, quality programs, job rotation, and other practices that are grouped under the heading of high-commitment or high-performance work systems. Surveys of employers show that these practices have diffused rapidly (Osterman 2000). These work systems require higher levels of skill and ask that employees make a greater commitment to the enterprise by offering ideas and paying more attention to quality. There is compelling evidence that high-performance systems yield enhanced productivity and quality (Ichiowski et al. 1996). Although part of the gains are due to intensified effort and peer pressure, employee surveys show that workers prefer these new systems to the alternative (Freeman and Rogers 1999).

The spread and success of high-performance systems appear inconsistent with other developments, notably the rise of insecurity and use of contingent employment. High-performance work systems require a degree of employee commitment, which seemingly is undermined by the other trends. Traditional industrial relations scholars would predict that firms could not successfully obtain the cooperation of their labor force without providing security in return. This, however, seems not to be true. One possibility is that employees sufficiently like the new systems that they are willing to cooperate without a quid pro quo. There is some evidence for this, but the more likely explanation is that the level of employment insecurity is sufficiently high that firms can call the shots without having to offer much in return.

18.4.5 Increased Diversity of Employment Systems 
We noted earlier that a nagging question about the accuracy of the original ILM research was how widely it applied to different occupations and types of organizations. Whatever the answer was some twenty years ago, in the past two decades it appears that the amount of diversity in employment models has increased. Prior to the era of restructuring, there were pressures towards uniformity or stability among what were seen as leading firms. In the past two decades much more diversity has emerged even within the core.

Within traditional sectors, new firms have challenged older ways of doing business. ${ }^{11}$ For example, automobiles used to be characterized by tight pattern bargaining, in which agreement in one of the Big Three firms was matched in the others. Today the Big Three vary significantly in their agreements. More important, a key nonunion segment-led by Japanese transplants-has emerged whose employment practices differ dramatically from the standard model. Likewise, in the large auto parts industry, the spread of an increasingly important nonunion sector has also added to the variation in employment patterns.

Much the same can be said of other industries. In telecommunications, Japanese transplants have not played an important role but the industry has moved a long way from the old world in which AT\&T set the dominant pattern for work organization in both local and long-distance service. The breakup of the old AT\&T system and the rise of nonunion carriers such as Sprint and $\mathrm{MCl}$ have also increased the variation in employment patterns.

One might argue that these examples illustrate growing variety in ILM rules but not a fundamental shift in the ILM idea. However, a more serious challenge to the notion of ILMs has emerged in the Silicon Valley. Many observers believe that how the Valley organizes employment represents a new pattern. The standard perception is that turnover in the Valley is very high and that high-skill employees are motivated by attachment to profession and learning opportunities, not by attachment to firm. Companies that are entirely nonunion work hard to create university-like employment settings (Rogers and Larson 1984). The tenuousness of attachments to firms is emphasized by the fact that the use of temporary help and contract labor is much higher in the Valley than elsewhere in America (Baru 2001).

More detailed research in the Silicon Valley suggests that there is important variation in employment strategies among 'standard' Valley firms. Based on systematic interviews with founders of new Silicon Valley companies, Baron, Hannan, and Burton (2001) identify five distinctive approaches to organizing work and motivating employees. Which strategy is selected has consequences for important outcomes, ranging from the time it takes to launch an Initial Public Offering (IPO) to the bureaucratic structure of the firm and the gender composition of the firm's employees. ${ }^{12}$ Whereas the early ILM literature distinguished two types of employment relationships, 'good' and 'bad' (aka core and periphery; primary and secondary; traditional and transformed, etc.), and proposed that ILMs existed in the 'good', there is growing evidence that there are more than two types of employment relationships.

\subsection{The Research Agenda}

\footnotetext{
${ }^{11}$ An excellent study that documents the trends described in this paragraph and makes the point about growing diversity is Katz and Darbishire (2000).

12 These five strategies are termed 'star', 'engineering', 'commitment', 'bureaucracy', and 'autocracy'. They vary according to what kinds of incentives are used to maintain attachment to the firm (e.g. a community of peers, a familial feeling, money), and what kinds of control and career systems are utilized.
} 
It is apparent that there have been substantial changes in how work is organized. There is a great deal of research to be done in understanding what has happened and the implications. In this final section, we describe what we see as an emerging research agenda.

We still lack a good understanding of what is driving many of these labor market developments. The standard list of suspects emphasizes factors that increase the pressure on firms to maximize profits and to reduce the possibilities of slack or rent sharing. These pressures include heightened product market competition, changes in corporate governance, and the role of the stock market. We agree that these are important, but we also believe that some deeper underlying constraints may have changed. For example, there is some evidence-both in the research literature and in policy discussions - that the spread of new technologies has made skills more general (Gould 2002). If this is true, then the gains to be had from ILMs are reduced. Similarly, the spread of information technology has opened the possibilities of new organizational designs (such as increased ability to outsource), which in turn have implications for the structuring of careers. Finally, changes in the broad political environment may have eased constraints managers feel as they consider how to approach their workforce. Understanding the role of these factors is partly the province of the kind of careful historical investigation that characterized the earlier rounds of research on ILMs. It may also be furthered by particular research strategies, such as taking advantage of geographical variation in the constraints facing employers.

A second set of research questions centers on developing a deeper understanding of how the institution of ILMs is evolving. At one level this involves asking about how firms are changing their strategies for organizing work. For example, researchers have noted an increased willingness of companies with longstanding ILMs to open up previously closed job ladders and hire from the outside. How widespread is this and what are the implications? More generally, what do careers now look like within organizations that have flattened their hierarchies and have established partnerships with other firms involving a substantial interpenetration of activities across traditional boundaries? Other researchers have emphasized how the ILMs of newer firms (such as those in the Silicon Valley) differ from older models. Just what these career systems look like and what is the significance of their departures from the standard model seem to us to be important questions. There is also the question noted earlier: how can firms reconcile the implementation of high-performance work systems with continued employment insecurity?

A third set of questions about what is happening emerges from the spread of structured careers outside of traditional firms. Traditionally, careers of this sort have been predominately in either construction craft jobs, certain professions, or in the bad jobs of the secondary labor market. However, the increased importance of contingent employment and independent contractors, combined with the role played by staffing firms in the labor market as well as the spread of peer groups that provide training and job search support (e.g. the International Webmasters Association or the New York New Media Association), suggests that these non-conventional career patterns may be taking on greater importance. Researchers are beginning to investigate these patterns more deeply, and this appears to us to be a fruitful area (Fernandez-Mateo 2002; Kunda, Barley, and Evans 2002).

One implication of the foregoing discussion is that the loosening of ties between employee and firm means that work may increasingly be organized around occupations rather than firms. These 'occupational labor markets' over time may come to replace some of the functions played by firm-based ILMs (Tolbert 1996). Put differently (and using the vocabulary of unions), more work may be organized along craft, as opposed to industrial, lines. 
The deepest question, however, is whether the idea of ILMs is still relevant. Recall that in our view the key idea driving the ILM literature is that social forces-customs, norms, power-shape employment relationships. Yet many observers believe that in recent years the market has pushed these considerations aside and that the changes we observe reflect the triumph of market forces. Of course, work is still largely organized within firms and in this, almost tautological sense, ILMs are of continued relevance. But if organizations are merely the transmission belt of the market, then the core idea has lost power.

There is, it seems to us, no doubt that market forces have successfully pushed against the older organizational forms and transformed them (though not as extensively as the more heated popular discussion suggests). The question, however, is whether over time social factors will reassert their importance in determining employment configurations. We suspect that the answer is yes, that what we are witnessing is one stage in a cycle in which market and society push against each other. We think that norms, customs, and power will continue to play important roles even in the kind of new employment arrangements in which people construct careers across boundaries. We certainly believe that this is true within more conventionally defined firms. Over time new customs and norms will arise; these will not simply be reflections of market considerations, and they will take on a power (and inertia) of their own. An important, and open, question is whether the basis of these social pressures will continue to be firms or, rather, whether new configurations will arise around occupations. A substantial shift from the firm to another form of organization would be a substantial change and there are certainly signs (as we have seen) that such a shift is possible. Our best guess is that firms will continue to be the dominant organizing device in the labor market but that occupations will emerge as more important than in the past. We also think that employees will find new ways to deploy power to protect their interests. Mapping and understanding just how all of this plays out will certainly be one of the most important, and interesting, research endeavors in this field.

However, our view that social factors will continue to be important in the labor market should be taken as a hypothesis, one that would constitute a core element in what we see as the emerging research agenda that can only be effectively pursued in a grounded and interdisciplinary fashion. 


\section{References}

Abbott, A. (1988). The System of Professions: An Essay on the Division of Expert Labor. Chicago: University of Chicago Press.

Abraham, K., and Taylor, S. (1996). 'Firms' Use of Outside Contractors: Theory and Evidence'. Journal of Labor Economics, 14/3: 394-424.

Arthur, M., and Rousseau, D. (eds.) (1996). The Boundaryless Career. New York: Oxford University Press.

Autor, D. H. (2001). 'Outsourcing at Will: The Contribution of Unjust Dismissal Doctrine to the Growth of Employment Outsourcing'. NBER Working Paper No. 7557.

Baker, G., Gibbs, M., and Holmstrom, B. (1994a). 'The Internal Economics of the Firm: Evidence from Personnel Data'. Quarterly Journal of Economics, 109: 881-919.

(1994b). 'The Wage Policy of a Firm'. Quarterly Journal of Economics, 109: 921-55.

Barley, S., and kunda, G. (1992). 'Design and Devotion: Surges of Rational and Normative Ideologies of Control in Management Discourse'. Administrative Science Quarterly, 37/3: 363-99.

Baron, J. N., and Bielby, W. T. (1986). 'The Proliferation of Job Titles in Organizations'. Administrative Science Quarterly, 31: 561-86.

and Newman, A. E. (1990). 'For What It's Worth: Organizational and Occupational Factors Affecting the Value of Work Done by Women and Non-Whites'. American Sociological Review, 55/2: 155-75.

Hannan, M., and Burton, M. D. (2001). 'Labor Pains: Change in the Organizational Models and Employee Turnover in Young High-Tech Firms'. American Journal of Sociology, 106/4: 960-1012.

Baru, S. (2001). Working on the Margins: California's Growing Temporary Workforce. San Diego: Center on Policy Initiatives.

Bendix, R. (1956). Work and Authority in Industry: Ideologies of Management in the Course of Industrialization. Berkeley: University of California Press.

Berger, L. A., and Berger, D. R. (eds.) (2000). The Compensation Handbook. New York: McGraw-Hill.

Cappelli, P. (1999). 'Career Jobs Are Dead'. California Management Review, 42: 146-67.

Crozier, M. (1964). The Bureaucratic Phenomenon. Chicago: University of Chicago Press. 
Dimaggio, P. J., and Poweli, W. W. (1983). 'The Iron Cage Revisited: Institutional Isomorphism and Collective Rationality in Organizational Fields'. American Sociological Review, 48: 147-60.

Diprete, T. (1989). The Bureaucratic Labor Market: The Case of the Federal Civil Service. New York: Plenum Press.

Doeringer, P. B., and Piore, M. J. (1971). Internal Labor Markets and Manpower Analysis. Lexington, Mass.: Heath.

Farber, H. (2001). 'Job Loss in the United States, 1981-1999'. Working Paper No. 453, Industrial Relations Section, Princeton University.

and Hallock, K. F. (1999). 'Changing Stock Market Response to Announcements of Job Loss:

Evidence from 1970-97'. IRRA 51st Annual Paper and Proceedings, 26-34.

Fernandez-Mateo, I. (2002). 'Careers in Boundary Labor Markets: An Empirical Analysis of Creative IT Contractors' Job Histories'. Dissertation proposal, MIT Sloan School.

Freeman, R., and Rogers, J. (1999). What Workers Want. Ithaca, NY: Cornell University Press.

Gibbons, R., and Waldman, M. (2000). 'Careers in Organizations: Theory and Evidence', in O. Ashenfelter and D. Card (eds.), Handbook of Labor Economics. New York: Elsevier, 3: 2373-437.

Golden, L., and Appelbaum, E. (1992). 'What Was Driving the 1982-1988 Boom in Temporary Employment? Preference of Workers or Decisions and Power of Employers'. American Journal of Economics and Sociology, 51/4: 473-93.

Gould, E. (2002). 'Rising Wage Inequality, Comparative Advantage, and the Growing Importance of General Skills in the United States'. Journal of Labor Economics, 20/1: 105-47.

Gouldner, A. W. (1954). Pattern of Industrial Bureaucracy. Glencoe, Ill.: Free Press.

Guillen, M. (1994). Models of Management. Chicago: University of Chicago Press.

Houseman, S. (2001). 'Why Employers Use Flexible Staffing Arrangements: Evidence from an Establishment Survey'. Industrial and Labor Relations Review, 55/1: 149-70.

Kalleberg, A. L., and Erickcek, G. (forthcoming). 'Why Employers Use Temporary Help Employment in Tight Labor Markets: Evidence from Case Studies of Hospitals and Auto Suppliers'. Industrial and Labor Relations Review.

Ichniowski, C., Kochan, T., Levine, D., Olson, C., and Strauss, G. (1996). 'What Works at Work'. Industrial Relations, 35/3: 299-333.

Jackall, R. (1988). Moral Mazes. New York: Oxford University Press. 
Jacoby, S. (1985). Employing Bureaucracy: Managers, Unions, and the Transformation of Work in American Industry, 1900-1945. New York: Columbia University Press.

(1997). Modern Manors: Welfare Capitalism since the New Deal. Princeton, NJ: Princeton University Press.

(1999a). 'Are Career Jobs Headed for Extinction?' California Management Review, 42: 123-45.

(1999b). 'Reply: Premature Reports of Demise'. California Management Review, 42: 168-79.

Kanter, R. M. (1977). Men and Women of the Corporation. New York: Basic Books.

Katz, H., and Darbishire, O. (2000). Converging Divergences. Ithaca, NY: Cornell University Press.

Knoke, D. (2001). Changing Organization: Business Networks in the New Political Economy. Boulder, Colo.: Westview Press.

Kunda, G., Barley, S. R., and Evans, J. (2002). 'Why Do Contractors Contract? The Experience of Highly Skilled Technical Professionals in a Contingent Labor Market'. Industrial and Labor Relations Review, 55 : 234-61.

Lebow, D., Sheiner, L., Slifman, L., and Starr-McCluer, M. (1999). 'Recent Trends in Compensation Practices'. Working paper, Federal Reserve.

Levine, D. I., Belman, D., Charness, G., Groshen, E. L., and O'Shaughnessy, K. C. (2002). How New is the 'New Employment Contract'? Kalamazoo, Mich.: Upjohn Institute for Employment Research.

Mcgregor, D. (1960). The Human Side of Enterprise. New York: McGraw-Hill.

Mayo, E. (1945). The Social Problems of an Industrial Civilization. Boston: Harvard University.

Meyer, J. W., and Rowan, B. (1977). 'Institutionalized Organizations: Formal Structure as Myth and Ceremony'. American Journal of Sociology, 83: 340-63.

O'Shaughnessy, K. C., Levine, D. I., and Cappelli, P. (2000). 'Changes in Managerial Pay Structures, 19861992 and Rising Returns to Skill'. National Bureau of Economic Research. Working Paper No. 7730, Cambridge, Mass.

Osterman, P. (1987). 'Choice of Employment Systems in Internal Labor Markets'. Industrial Relations, 26: 46-67.

(1999). Securing Prosperity: The American Labor Market: How It Has Changed and What to Do

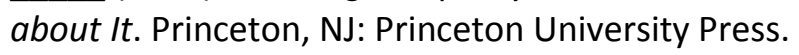

(2000). 'Work Reorganization in an Era of Restructuring'. Industrial and Labor Relations Review, 53/2: 176-96. 
Roethlisberger, F. J., and Dickson, W. J. (1939). Management and the Worker. Cambridge, Mass.: Harvard University Press.

Rogers, E. M., and Larson, J. K. (1984). Silicon Valley Fever: Growth of High-Technology Culture. New York: Basic Books.

Rosenbaum, J. (1984). Career Mobility in a Corporate Hierarchy. Orlando, Fla.: Academic Press.

Roy, D. (1952). 'Quota Restrictions and Goldbricking in a Machine Shop'. American Journal of Sociology, 57: 427-42.

Saxenian, A. (1994). Regional Advantage. Cambridge, Mass.: Harvard University Press.

Scott, W. R. (1992). Organizations: Rational, Natural, and Open Systems. Englewood Cliffs, NJ: Prentice Hall.

Sibson, R. E. (1990). Compensation. New York: American Management Association.

Tolbert, P. S. (1986). 'Organizations and Inequality: Sources of Earnings Differences between Male and Female Faculty'. Sociology of Education, 59: 227-36.

(1996). 'Occupations, Organizations, and Boundaryless Careers', in M. Arthur and D. Rousseau (eds.), The Boundaryless Career. New York: Oxford University Press, 331-49.

and Zucker, L. G. (1983). 'Institutional Sources of Change in the Formal Structure of Organizations:

The Diffusion of Civil Service Reform, 1880-1935'. Administrative Science Quarterly, 28: 22-39. 